Science has withstood these attacks and has captured some of the strongholds of the older culture. Birkbeck College can claim to have acted as éclaireur to the "march of mind" and to recapitulate the history of scientific instruction in Great Britain ; this proud claim should ensure the success of its appeal.

The College, as we have said, stands for education in a broad sense, but it stands also for another great principle--part-time education. Hundreds of examples of the value of part-time education could be cited from the records of the College, but the one selected by the Archbishop of Canterbury in his speech at the Mansion House meeting is of outstanding interest. Sidney Gilchrist Thomas (1850-85), a police court clerk, attended George Chaloner's chemistry class in the College. The lecturer remarked that "the man who eliminates phosphorus by means of the Bessemer converter will make his fortune". From 1860 onwards, Sir Henry Bessemer and many others had studied this problem, a problem of great economic importance, since its solution would render available vast deposits of iron ore in England, Germany and the United States. Gilchrist Thomas solved the problem and received the promised guerdon. This wealth was not, however, the incentive to the discovery, for his biographer states that "he held 'advanced' political and social views and had he lived he had intended to devote his fortune to the alleviation of the lives of the workers". The money was spent in philanthropic objects after his early death. "A rare young man", as Gladstone observed! Let it be added that the scientific equipment provided at the College at this period was of the simplest. The room, said Bernard $\mathrm{H}$. Becker in "Scientific London" (1874), might (were it not devoted to the use of science) be designated the back kitchen. A couple of glaring 'butcher's lights' illuminated a rough deal table from behind which Mr. Chaloner expounded the properties of carbonic acid gas. But he added, -and this sounds the keynote of the history of the College-_"the lecturer and the audience evidently mean business".

In recent years, the College has catered for two groups of students who are to be found in large numbers in London and the surrounding districts. The first consists largely of teachers, civil servants, technical chemists and others who have missed the usual university training and are willing to give their evenings to working for a degree. The second group comprises graduates in arts and science of London and other universities who have a keen desire to pursue post-graduate studies and research. For many years the lecture rooms and laboratories have been seriously overcrowded by both types, and each year a number of keen and deserving students has been refused admission owing to limitations of space.

New buildings and more space are urgently needed to enable the College to serve effectively the needs of the present generation. When the College was founded in 1823, two men in every three and nine women in every ten could neither read nor write. When it was rebuilt in 1883, elementary education was in its infancy. To-day the mesh of the scholarship net is so fine that the time is not far distant when all who are fitted for university education will be provided for in the ordinary course.

What then is Birkbeck's future? It has provided adult education in fundamental subjects; it has led its students along the paths of the polytechnic, and inspired them to scale the academic heights by degrees-now it has entered upon a greater role - the provision of opportunities for research for those whose everyday occupations are in other fields.

\title{
Schmidt and the Eels
}

\section{Danish Eel Investigations during Twenty-five Years}

$\mathrm{O}^{\mathrm{N}}$ June 22, sixty miles west of Ringkjöbing, Jutland, the research ship Dana, built by the British Admiralty during the War and sold to the Danish Government in 1921, was sunk in collision with a German trawler in a fog. Happily there was no loss of life; but, with her, was lost all her scientific equipment and the material of her latest cruises. Johannes Schmidt, who made the Dana famous, had died all too soon, a com. paratively young man, on February 21, 1933.
When his ship went down, it was as if a chapter of oceanographical history came to an end. The little brochure "Danish Eel Investigations During Twenty-five Years, 1905-1930", recently issued by the Carlsberg Foundation, Copenhagen, may be regarded as the epilogue to the story.

There is nothing new in this publication. The text is taken from Schmidt's report of his famous voyage round the world. It was his intention that the report, written in Danish, should be done into 


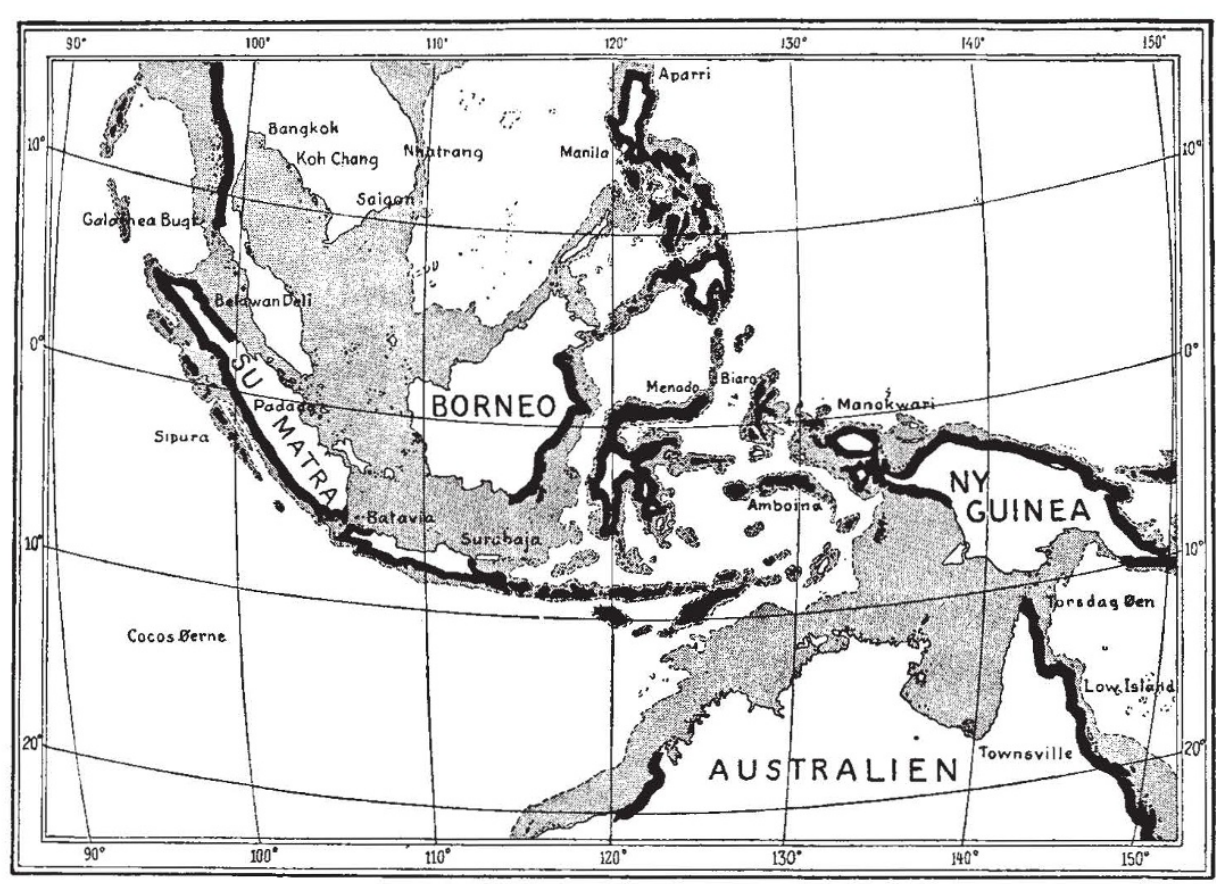

Fig. 1. Chart of Indo-Malaya showing distribution of the eel (in black). Shallow water (less than 200 metres deep) is shaded and deep water and land areas are white. Note that eels do not occur off coasts facing shallow water regions (Sumatra, Java, Borneo, Siam, etc.) guide to the literature. One cannot read it without a feeling of deep regret that he did not live to pursue the subject further and to check bis own conclusions, as we may be sure that he would have done if he had not been cut off in his prime.

As a summary statement of the facts and Schmidt's interpretation of them, this document is a master. piece of compression. Schmidt believed that he h a d successfully identified every species of the
English, or at least French. That intention was not fulfilled, but Schmidt's summary record of the Danish eel investigations, of which he had been the leader since 1905, has been lifted out of the report and published in English. The record is illustrated and expanded by the addition of figures, with appropriate text, from others of Schmidt's papers, and the brochure concludes with a list of Schmidt's papers on eel investigations and a brief record, with illustrative charts, of his various eel expeditions. Three of the illustrations are reproduced herewith by courtesy of the Carlsberg Founda. tion.

For those who followed Schmidt's voyages as they took place, this paper is an interesting summary of their results, as regards eels, and of his conclusions from them. To the student approaching the question for the first time, it will be a stimulating introduction to what Schmidt describes as "the Eel question", and a useful

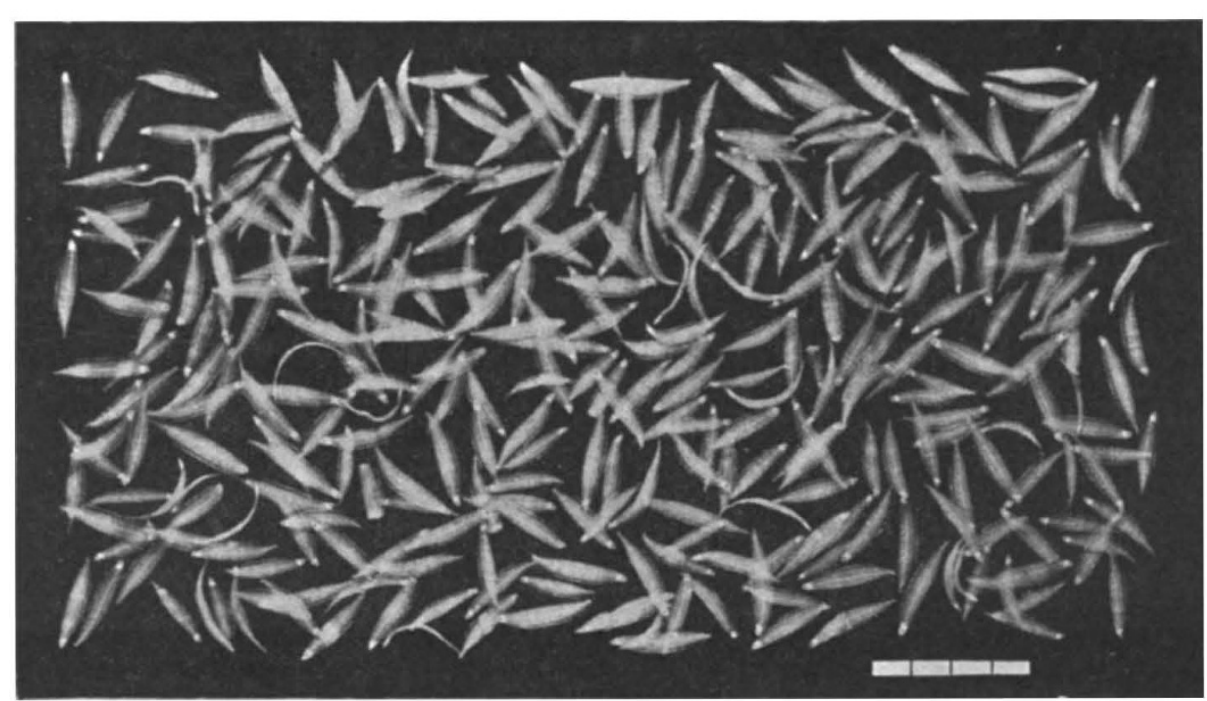

FIG. 2. Larvæ of the European eel from the Sargasso Sea. Note the small size and the uniformity of the larvæ. Scale shows centimetres. 
which demonstrate in truly remarkable fashion how the concentrations of small larval eels are found in the deepest waters and how, even among the islands of Indo-Malaya, eels are not found at all on the coasts facing extensive areas of shallow water (Fig. 1).

Another important fact is that, just as the larval period of the North American eel, which has a less distance to travel, is appreciably shorter than that of the European eel, so the eels of Indo-Malaya, which Schmidt studied most intensively of the Pacific species, are still more rapidly metamorphosed. Although some of them reach a very much greater size than the European eel, their the east or west coast of South America, and none on the west coast of Africa, it is difficult to reconcile with this conclusion the distribution, as proved by Schmidt, of the European and the North American eel, unless, indeed, one glances back in imagination over the ages to some remote, cataclysmic change of the earth's crust and of the distribution of the oceans.

One may hesitate to accept without question such a far-reaching conclusion, but one cannot read this paper without renewed admiration for Schmidt's genius. In particular, the thoroughness with which he did his work, and the forethought with which he laid his plans are remarkable.

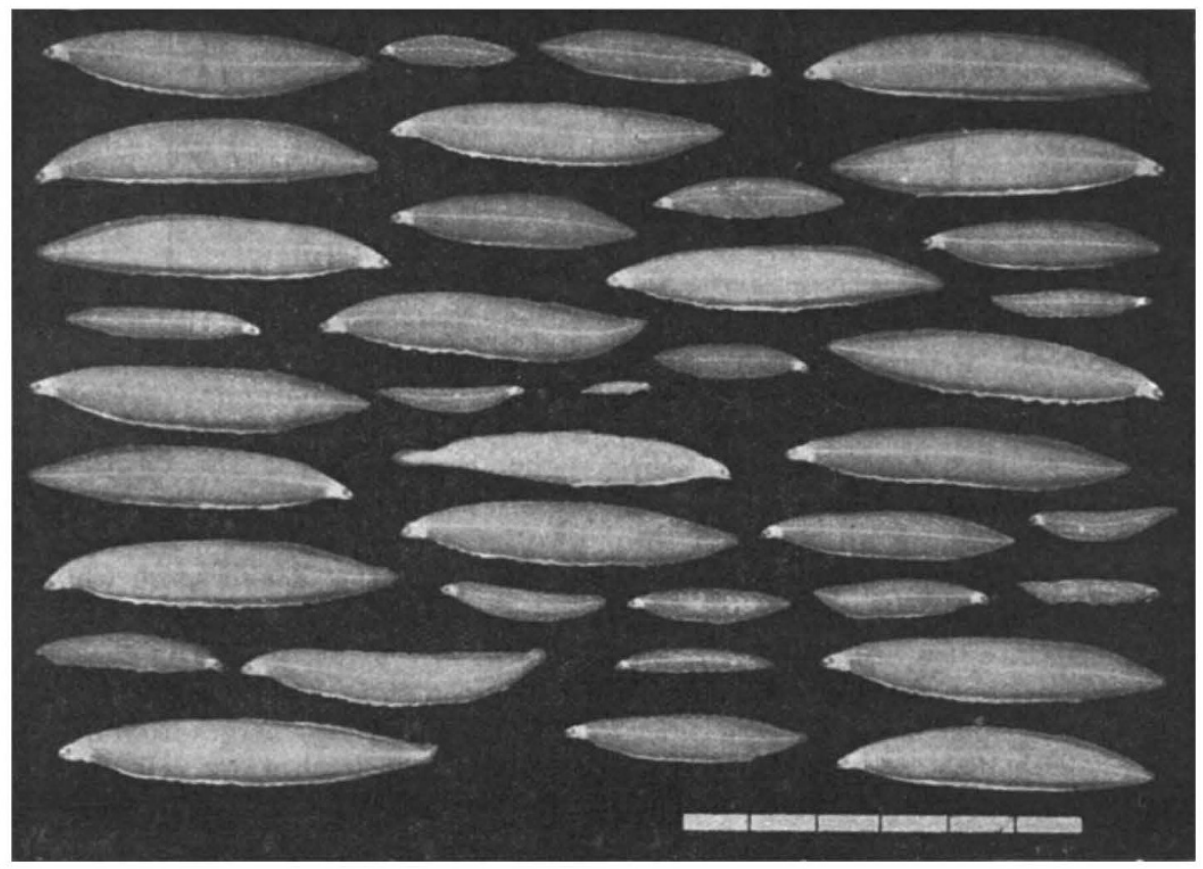

FIG. 3. Larvæ of freshwater eels from the Mentawel Deep, west of Sumatra. All stages of development are present Scale shows centimetres.

larvæ, both in the earliest and in the latest stages, are much smaller. Moreover, whereas in the Sargasso Sea a haul of eel larvæ will be all small and practically identical in size (Fig. 2), in the Mentawei Deep, west of and at no great distance from Sumatra, which is the spawning area of three species, they are found together at all stages of development, and, nearer to the coast, the larger larvæ and the elvers are found freely intermingled (Fig. 3).

Schmidt's most remarkable conclusion is that not only are all the fresh-water eels of tropical origin, but also that "the most westerly equatorial Pacific is the domicile of the Eel genus from which it has distributed itself over those parts of the world where conditions are favourable for it to thrive". Considering that no eels are found on
From 1922 onwards, thousands of eels from all parts of the world were examined at Copenhagen, with the view of obtaining information as to the distribution of each species and such knowledge of the adult eels as would facilitate the recognition of their larval forms. In 1926, Schmidt himself visited Australia, New Zealand and Tahiti, for the purpose of completing his records. Not until he was satisfied that he had thoroughly charted the distribution of the eels in fresh water did he embark upon his round-the-world expedition, the chief purpose of which was to chart their spawning places in the sea, and thus, while elucidating their life-history, to throw a new light on the European species, chiefly distinguished from its relations of the Pacific and Indian Oceans by its amazing instinct for travel. 